\title{
Faktor Risiko Timbulnya Kelainan Kongenital
}

\section{Risk Factors of Congenital Anomalies}

\section{Mitayani Purwoko}

Staf Departemen Biologi Kedokteran Fakultas Kedokteran Universitas Muhammadiyah Palembang

\begin{abstract}
ABSTRAK
Usia harapan hidup seseorang dapat bervariasi tergantung di mana orang tersebut dibesarkan. Kesenjangan dalam bidang kesehatan terutama dirasakan pada penderita kelainan kongenital. Kelainan kongenital adalah suatu kondisi ketidaknormalan struktur atau fungsi tubuh yang muncul saat lahir. Apabila bayi terlahir dengan baik maka dapat menyebabkan disabilitas seumur hidup dan menyebabkan pengaruh negatif bagi keluarga dan lingkungan. Beberapa faktor risiko yang memiliki peranan penting dalam timbulnya kelainan kongenital adalah nutrisi, usia orang tua, dan lingkungan. Konsumsi nutrisi yang tidak adekuat, konsumsi obat-obatan selama kehamilan, usia ibu dan ayah saat terjadi pembuahan, serta adanya paparan debu dan asap rokok pada lingkungan dapat menyebabkan kelainan kongenital.

Kata kunci: faktor risiko kelainan kongenital, cacat bawaan, kelainan janin
\end{abstract}

\section{ABSTRACT}

Life expectancy vary depends on the location of peoples' live. The gap in health sector especially happens among peoples who were born with congenital anomalies. Congenital anomaly is a condition of abnormality in structures and or functions of some parts of body. If a baby who was born with congenital anomaly and can live well, he will suffers disability during his life and can give negative effect for his family. Some risk factors that could cause congenital anomalies are nutrition, parental age, and environment. Inadequate nutrition of pregnant woman, medication during pregnancy, advanced paternal age, and tobacco smoke exposure can cause congenital anomalies.

Keywords: risk factors of congenital anomalies, birth defect, fetal anomalies

\section{PENDAHULUAN}

Usia harapan hidup seseorang dapat bervariasi tergantung di mana orang tersebut dibesarkan. Angka harapan hidup di negara maju seperti di Eropa lebih tinggi daripada angka harapan hidup di negara Afrika. Selain perbedaan angka harapan hidup antarnegara, terdapat juga perbedaan angka harapan hidup antarpenduduk dalam satu negara. Penduduk yang miskin memiliki angka harapan hidup yang lebih rendah dibandingkan penduduk yang kaya. Ketidakadilan sosial dapat membunuh manusia dalam skala besar, oleh karena itulah kita harus mengurangi kesenjangan dalam bidang kesetaraan hak untuk memperoleh kesehatan yang sama rata.(1)
Kesenjangan dalam bidang kesehatan terutama dirasakan pada penderita kelainan kongenital. Kelainan kongenital adalah suatu kondisi ketidaknormalan struktur atau fungsi tubuh yang muncul saat lahir. Kelainan kongenital dapat menyebabkan abortus spontan atau lahir mati. Apabila bayi terlahir dengan baik maka dapat menyebabkan disabilitas seumur hidup dan menyebabkan pengaruh negatif bagi keluarga dan lingkungan. WHO memperkirakan 7\% dari seluruh kematian neonatus di dunia adalah karena kelainan kongenital. Kelainan kongenital dapat timbul akibat berbagai etiologi, misalnya karena mutasi genetik, virus, trauma, dll.(2)

Negara maju seperti Amerika Serikat saja mengalami peningkatan prevalensi hipospadia 
(suatu kelainan kongenital pada penis) dari 6,1 per 1.000 kelahiran menjadi 6,8 per 1.000 kelahiran selama periode 1997-2012.(3) Hasil Riset Kesehatan Dasar 2013 menunjukkan prevalensi bibir sumbing sebesar 0,08\% dengan kata lain 8 dari 100 anak menderita bibir sumbing.(4) Pusat Data dan Informasi Kementerian Kesehatan RI mengeluarkan buletin mengenai kelainan bawaan. Dalam buletin tersebut dinyatakan bahwa prevalensi bayi dengan kelainan bawaan di Indonesia sebesar 59,3 per 1.000 kelahiran. Angka ini termasuk tinggi di antara negara-negara Asia Tenggara.(5)

Saat ini masih sedikit sekali publikasi ilmiah terkait angka kejadian kelainan kongenital di Indonesia. Saat ini baru diketahui jumlah bayi dengan kelainan kongenital di RS Moehamad Hoesin Palembang pada tahun 2015 sejumlah 108 bayi.(6) Namun dari penelitian ini tidak diketahui dari berapa jumlah kelahiran sehingga tidak bisa ditentukan persentasenya. Kemudian ada publikasi mengenai prevalensi kelainan kongenital di RS Abdul Muluk Bandar Lampung pada tahun 20062007 yaitu sebesar $0,6 \%$ dari total kelahiran.(7)

\section{Faktor Risiko}

Beberapa faktor risiko yang berperan dalam timbulnya kelainan kongenital adalah sebagai berikut:

a) Nutrisi
Pangan yang dikonsumsi seorang wanita saat belum hamil dan saat hamil sangat menentukan tingkat kesehatan janin yang dikandungnya. Janin mendapat nutrisi penuh dari plasenta yang menempel pada rahim sang wanita.

Suatu penelitian di Turki menemukan bahwa bayi-bayi dengan celah langit-langit mulut (cleft palate) dan celah bibir (cleft lip palate) memiliki riwayat intrauterine growth retardation (IUGR) atau prematur.(8) IUGR dapat timbul apabila sang ibu tidak memperhatikan gizinya selama hamil, sehingga perkembangan janinnya tidak baik.

Calon ibu yang kekurangan asam folat dari nutrisinya dapat menyebabkan janinnya lahir dengan cacat pada tabung saraf (neural tube defect $)$. Kadar asam folat yang dibutuhkan oleh ibu hamil agar janinnya terhindar dari cacat tabung saraf adalah 400 mikrogram per hari.(10) Kadar ini bisa diperoleh dengan mengonsumsi satu tablet asam folat per hari atau dengan mengonsumsi makanan tinggi asam folat misalnya kacang-kacangan, buah jeruk, brokoli, dan bayam.
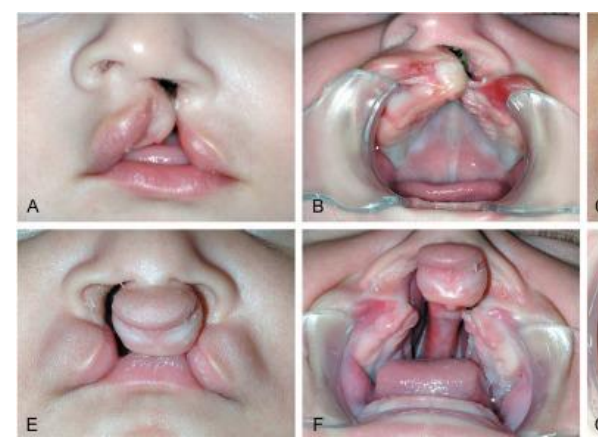
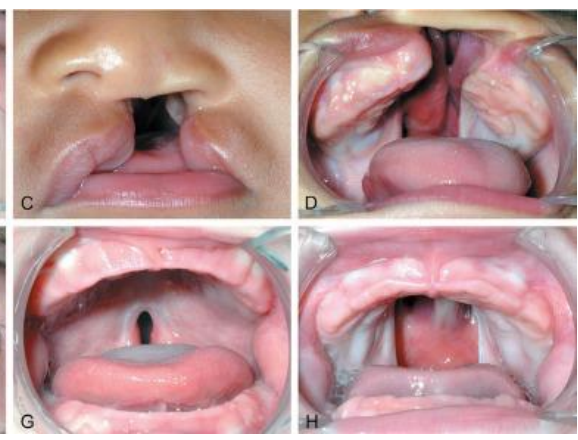
Gambar 1. Celah pada bibir dan langit-langit mulut.(9)

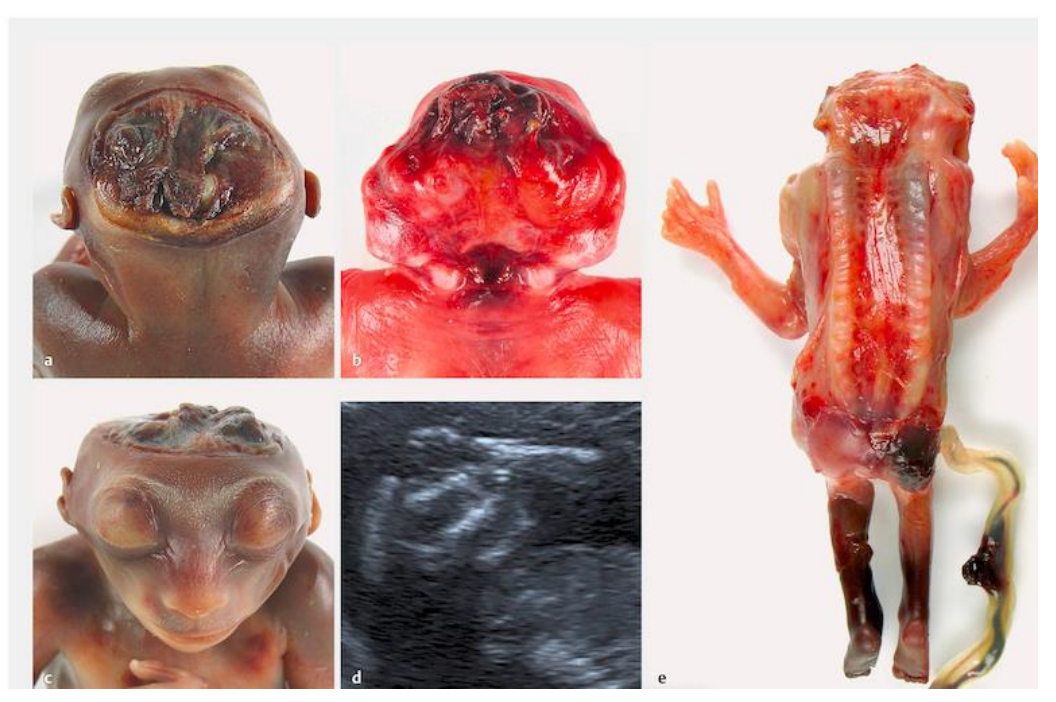

Gambar 2. Anensefali sebagai salah satu bentuk neural tube defect.(11)

Faktor risiko yang paling besar menyebabkan kelainan kongenital di Provinsi Shanxi, China, adalah tidak mengonsumsi asam folat selama hamil, disusul gaya hidup tidak sehat dan pendidikan ibu yang rendah.(12) Selain asam folat, calon ibu yang kekurangan yodium akan menyebabkan janinnya lahir dengan kadar yodium rendah sehingga janin tersebut akan tumbuh dengan disabilitas intelektual. Sebuah penelitian di Australia menemukan asosiasi antara defisiensi yodium ringan pada ibu selama masa kehamilan dengan gangguan memori dan kecepatan proses mendengar pada anak yang dikandungnya.(13)

Beberapa bahan pangan mengandung insektisida. Bila insektisida ini terkonsumsi oleh calon ibu secara rutin dan dalam jumlah yang banyak dapat menyebabkan gangguan pertumbuhan janin sehingga janin kemungkinan lahir dengan kecacatan bawaan. Sebuah penelitian di Picardy, Perancis, menemukan hubungan antara konsumsi pangan mengandung insektisida dengan timbulnya kelainan penis berupa isolated bypospadias.(14)

b) Konsumsi obat

Ibu yang mengonsumsi obat antimuntah Ondansetron pada trimester pertama kehamilan memiliki risiko lebih besar melahirkan bayi dengan kelainan kongenital pada jantung dan celah orofasial.(15) Ondansetron dapat menyebabkan pemanjangan gelombang QT dan aritmia jantung. Efek teratogeniknya timbul akibat aritmia jantung embrio, terganggunya suplai darah dan oksigen pada embrio, serta kerusakan reperfusi (16). Namun, hingga saat ini masih ada pro kontra terkait efek teratogenik Ondansetron karena 
ada penelitian yang tidak menemukan asosiasi antara konsumsi Ondansetron pada ibu hamil dengan kelainan kongenital (17).

Ibu hamil sering menderita keputihan dan diobati dengan obat antifungal. Namun, konsumsi obat antifungal Fluconazole diketahui dapat menimbulkan celah bibir dan langit-langit (cleft lip and palate) serta kelainan pembuluh darah besar (18).

c) Usia orang tua

Usia ibu dan usia ayah yang tua saat terjadi pembuahan dapat meningkatkan risiko timbulnya kelainan kongenital pada janin yang dikandung. Dalam sebuah penelitian di Norwegia, ditemukan hubungan antara usia orang tua yang tua dengan timbulnya cleft palate (19). Sebuah penelitian yang menggunakan data dari The National Birth Defects Prevention Study mendapatkan hasil bahwa peningkatan usia ayah meningkatkan risiko timbulnya cleft palate, hernia diafragma, dan kelainan kongenital pada jantung janin. Penelitian ini juga menemukan bahwa usia ayah yang muda juga dapat menimbulkan gastroschisis. Usia ayah yang termasuk tua pada saat pembuahan dikaitkan dengan meningkatnya mutasi DNA dan aberasi kromosom dalam sperma (20). Pengaruh usia ayah terhadap timbulnya kelainan kongenital masih kontroversial karena ada penelitian yang menyatakan bahwa tidak ada hubungan antara kedua hal tersebut. Salah satunya adalah penelitian kohort retrospektif di Ohio yang menyatakan bahwa tidak ada hubungan antara usia ayah yang tua dengan timbulnya kelainan kongenital (21). d) Lingkungan

Seorang ibu hamil yang merokok dapat menyebabkan timbulnya kelainan kongenital pada janin yang dikandungnya. Hal ini dibuktikan dalam suatu penelitian di Brazil dimana ditemukan hubungan antara ibu yang merokok dengan timbulnya cleft lip palate pada janinnya. Mekanisme mengapa merokok dapat menyebabkan kelainan kongenital pada janin masih belum dimengerti. Ada dugaan bahwa paparan komponen rokok pada janin dalam kandungan dapat menginduksi gengen dengan jalur metabolism tertentu, misalnya glutathione S-transferase theta (GSTT1) atau nitric oxide synthase-3 (NOS3). Induksi GSTT1 kemungkinan menyebabkan defisiensi pada jalur detoksifikasi sehingga menimbulkan kelainan kongenital (22). Sebuah penelitian di China juga menguatkan hal tersebut dimana ibu hamil yang terpapar asap rokok dari lingkungannya lebih besar kemungkinannya melahirkan janin dengan kelainan jantung kongenital (23).

Jika ibu terpapar polusi udara saat hamil maka janin dapat mengalami kelainan bawaan, terutama pada bagian genital dan dinding perut. $(24,25)$ Salah satu contoh kelainan kongenital pada bagian genital adalah hipospadia, yaitu posisi lubang penis di bagian bawah batang penis, bukan pada bagian ujungnya.

Vol. 6 No.1 Februari 2019 


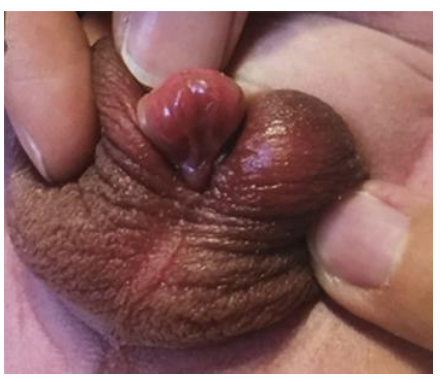

Gambar 3. Hipospadia.(26)

\section{Upaya Pencegahan}

The Commission on Social Determinants of
Health memberikan tiga rekomendasi untuk menutup celah ketidakseimbangan kesehatan pada generasi berikutnya. Rekomendasi tersebut adalah meningkatkan kondisi kehidupan sehari-hari; mengatasi ketidakseimbangan penyebaran kekuasaan, ekonomi, dan sumber daya alam; serta mengukur dan memahami masalah yang sebenarnya dan menentukan hasil dari aksi yang dilakukan untuk mengatasi masalah tersebut.(1)

Perkembangan otak pada masa awal kehidupan anak yang akan berpengaruh sepanjang kehidupannya. Nutrisi yang baik sangat penting dan dimulai sebelum kehamilan dengan pemberian nutrisi yang adekuat bagi ibu. Nutrisi yang baik ini terus diberikan sebelum, selama, dan setelah kehamilan bagi ibu dan anak, dan untuk anak diteruskan hingga tahun-tahun pertama kehidupan.(1) Bila calon ibu maupun ibu hamil tinggal di daerah pertanian yang sering menggunakan insektisida, maka mereka sebaiknya tidak diizinkan bekerja dengan insektisida sehingga hanya sedikit terpapar. Anggota keluarga perlu diberi edukasi terkait tidak merokok di sekitar ibu hamil karena paparan asap rokok secara rutin dapat menyebabkan kelainan kongenital pada janin.

\section{Simpulan}

Konsumsi nutrisi, konsumsi obat, usia orang tua, dan lingkungan sekitar ibu hamil memiliki peranan dalam menyebabkan kelainan kongenital pada janin.

\section{Daftar Pustaka}

1. Marmot M, Friel S, Bell R, Houweling TA, Taylor S. Closing the gap in a generation: health equity through action on the social determinants of health. Lancet. 2008;372(9650):1661-9.

2. World Health Organization. Birth Defects. 2010

3. Chen M-J, Karaviti LP, Roth DR, Schlomer BJ. Birth prevalence of hypospadias and hypospadias risk factors in newborn males in the United States from 1997 to 2012. J Pediatr Urol. 2018;1-7.

4. Badan Penelitian dan Pengembangan Kesehatan. Riset Kesehatan Dasar: Riskesdas 2013. Jakarta: BKementerian Kesehatan Republik Indonesia. Jakarta; 2013.

5. Kementerian Kesehatan RI. Kelainan Bawaan. Infodatin. 2018;

6. Maritska Z, Kinanti SRA. Kejadian dan Distribusi Kelainan Kongenital Pada Bayi Baru Lahir di RS dr. Moehammad Hoesin Palembang Periode Januari-November 2015. J Kedokt Unila. 2016;1(Oktober 2016):34750 .

7. Mustofa S, Susmiarsih T, Wikaningrum R. Prevalensi bayi lahir cacat (Malformasi Kongenital) di Rumah Sakit Pendidikan Fakultas Kedokteran Universitas YARSI. J Kedokt Yars. 2009;17(2):101-10.

8. Altunhan H, Annagür A, Konak M, Ertugrul S, Örs R, Koç H. The incidence of congenital anomalies associated with cleft palate/cleft lip and palate in neonates in the Konya region, Turkey. Br J Oral Maxillofac Surg. 2012;50(6):541-4.

9. Freitas JA de S, Neves LT das, Almeida ALPF de, Garib DG, Trindade-Suedam IK, Yaedú RYF, et al. Rehabilitative treatment of cleft lip and palate: experience of the Hospital for Rehabilitation of Craniofacial 
Anomalies/USP (HRAC/USP) - Part 1: overall aspects. J Appl Oral Sci. 2012;20(1):9-15.

10. Gool JD Van, Hirche H, Lax H, Schaepdrijver L De. Folic acid and primary prevention of neural tube defects : A review. Reprod Toxicol. 2018;80(March):73-84.

11. Schoner K, Axt-Fliedner R, Bald R, Fritz B, Kohlhase J, Kohl T, et al. Fetal Pathology of Neural Tube Defects - An Overview of 68 Cases. Geburtshilfe Frauenheilkd. 2017;77(05):495-507.

12. Zhu Z, Cheng Y, Yang W, Li D, Yang X, Liu D, et al. Who Should Be Targeted for the Prevention of Birth Defects? A Latent Class Analysis Based on a Large, PopulationBased, Cross-Sectional Study in Shaanxi Province, Western China. PLoS One. 2016;11(5):1-16.

13. Hynes KL, Otahal P, Burgess JR, Oddy WH, Hay I. Reduced educational outcomes persist into adolescence following mild iodine deficiency in Utero, despite adequacy in childhood: 15-Year Follow-Up of the gestational iodine cohort investigating auditory processing speed and working memory. Nutrients. 2017;9(12):1-19.

14. Haraux E, Tourneux P, Kouakam C, Stephan-Blanchard E, Boudailliez B, Leke A, et al. Isolated hypospadias: The impact of prenatal exposure to pesticides, as determined by meconium analysis. Environ Int. 2018;119(June):20-5.

15. Zambelli-weiner A, Via C, Yuen M, Weiner DJ, Kirby RS. First trimester ondansetron exposure and risk of structural birth defects. Reprod Toxicol. 2019;83(March 2018):14-20.

16. Danielsson B, Norstedt B, Källén B. Use of ondansetron during pregnancy and congenital malformations in the infant. Reprod Toxicol. 2014;50:134-7.

17. Fejzo MS, Macgibbon KW, Mullin PM. Ondansetron in pregnancy and risk of adverse fetal outcomes in the United States. Reprod Toxicol. 2016;62:87-91.
18. Ms MMH, Carter TC, Browne ML, Romitti PA, Cunniff CM, Druschel CM, et al. Fluconazole use and birth defects in the National Birth Defects Prevention Study. Am J Obstet Gynecol. 2016;214(5):657.e1657.e9.

19. Berg E, Lie RT, Sivertsen $\AA$, Haaland $\varnothing A$. Annals of Epidemiology Parental age and the risk of isolated cleft lip : a registry-based study. Ann Epidemiol. 2015;25(12):942947.e1.

20. Green RF, Devine O, Crider KS, Olney RS, Archer N, Olshan AF, et al. Association of Paternal Age and Risk for Major Congenital Anomalies From the National Birth Defects Prevention Study , 1997 to 2004. Ann Epidemiol. 2010;20(3):241-9.

21. Hurley EG, Defranco EA. Influence of paternal age on perinatal outcomes. Am J Obstet Gynecol. 2017;217(5):566.e1-566.e6.

22. Martelli DRB, Coletta RD, Oliveira EA, Swerts MSO, Rodrigues LAM, Oliveira MC, et al. Association between maternal smoking, gender, and cleft lip and palate. Braz J Otorhinolaryngol. 2015;81(5):514-9.

23. Liu X, Nie Z, Chen J, Guo X, Ou Y, Chen G, et al. Does maternal environmental tobacco smoke interact with social- demographics and environmental factors on congenital heart defects ? * Environ Pollut. 2018;234:214-22.

24. Ren S, Haynes E, Hall E, Hossain M, Chen A, Muglia L, et al. Periconception Exposure to Air Pollution and Risk of Congenital Malformations. J Pediatr. 2017;193:76-84.e6.

25. Salavati N, Strak M, Burgerhof JGM, de Walle HEK, Erwich JJHM, Bakker MK. The association of air pollution with congenital anomalies: An exploratory study in the northern Netherlands. Int J Hyg Environ Health. 2018;221(7):1061-7.

26. Lin TW, Wang JT. Prenatal Diagnosis of Hypospadias - A Case Report. J Med Ultrasound. 2017;25(2):115-7. 